] O U R A L O F

French and Francophone Philosophy
REVUE DE LA

philosophie française et de langue française

\title{
Mysticism and War: Reflections on Bergson and his Reception During World War I
}

Donna V. Jones

Journal of French and Francophone Philosophy - Revue de la philosophie française et de langue française, Vol XXIV, No 2 (2016) 10-20.

\author{
Vol XXIV, No 2 (2016) \\ ISSN 1936-6280 (print) \\ ISSN 2155-1162 (online) \\ DOI $10.5195 /$ jffp. 2016.768 \\ www.jffp.org
}

\section{(c)) EY-NC-ND}

This work is licensed under a Creative Commons Attribution-Noncommercial-No Derivative Works 3.0 United States License.

\section{ULIS D-Sunt}

This journal is operated by the University Library System of the University of Pittsburgh as part of its D-Scribe Digital Publishing Program, and is co-sponsored by the University of Pittsburgh Press 


\title{
Mysticism and War
}

Reflections on Bergson and his Reception During World War I

\author{
Donna $V$. Jones \\ University of California, Berkeley
}

In his brilliant lecture, "Perception of Change," delivered at Oxford University in 1911, Henri Bergson outlines the radical understanding of metaphysics that he had introduced into thought. ${ }^{1}$ For Bergson, absolute knowledge of the world, time and oneness are defended as possible but not through ratiocination that takes us beyond the senses-Bergson accepts Immanuel Kant's argument that reason results in antinomy. Bergson argues that only through intuition awakened in us most often by great works of art can we attain the vista of metaphysical truths. But intuition itself can be awakened by art only if the mind is freed from the burdens of action. For example, to act on the world we imagine ourselves as a fixed center of action and the object on which we are acting as itself also a fixed entity. Without this supposition, instrumental action would hardly be possible; put differently, the assumption is a condition of possibility of action, for otherwise we would be immersed in flows on which there would be nothing to take hold.

However, in a memorable image-an image that prefigures his interest in the relativity of simultaneity - Bergson suggested what we have in any subject-object relation are two passengers (the subject and the object) moving on trains parallel to each other at the same speed, oblivious to the motion that carries both. Practical activity keeps us ignorant to the fundamentally processual nature of the world and to process itself as that which condenses time as an interpenetrated flow (for this assumption Bergson would hope that microphysics of flows would vindicate him). ${ }^{2}$ For us to intuit metaphysical truth we have not to act but to contemplate. In this sense his metaphysics is intuitive, meaning here that it is a mindful activity antithetical to practical action, much less violent action.

As removed from the exigencies of action as it may appear, Bergson's metaphysics is not premised on mindful activities that raise us above the world of perception, but rather depends on mindful activity intuitive of 
what it already experienced in the world, albeit dimly as we most often cloud our own experience with the categories and thought-patterns in terms of which we manipulate the world. Bergson gives us a wonderful example of his intuitive metaphysics - the appreciation of a melody freed from extraneous thoughts such as images of the graphical notes on the score or the physical feel of the instruments being played. Freed from images or memories that would enable music-playing, the mind becomes free for an intuitive plunge into melody. (Bergson also repeats his philosophically momentous argument that just a melody is only what it is as a whole, motion is an indivisible whole, not discrete points out of which the whole could in fact never be recomposed).

It would be incorrect to refer to Bergson's intuitive metaphysics as mystical in any traditional sense. If Max Weber's Protestants were worldly ascetics as they did not use profits to satisfy bodily pleasures but to accumulate capital and rationalize enterprises-I leave aside here active historiographic controversy over both the actual ascetism of Protestant cults and the importance of religion to institutional change--Bergson's metaphysicians are worldly mystics as they turn away from worldly action decidedly not to find a path towards Platonic transcendence but to be true to worldly experience. What breaks down as the world is intuited, is reality, which is simply that framing of the world for the purposes of practical activity with already organized ways of life. Bergson holds out against reality the world itself, not extra-worldly transcendence. I others, antirealism need not lead out of this world; on the contrary. The world is more concrete than reality; reality is an abstraction of more fundamental processes, if not itself a myth or at least intersubjective assumptions shared for the purposes of the coordinated manipulation of the world. For Bergson, then, Western thought had not become singularly worldly in historical terms due to its more practical hold on reality; on the contrary, the achievement of worldly thinking depended not on scientific thinking disciplined in a Humean empiricist fashion by the reality principle but on his own philosophical revolution - an intuitive metaphysics that placed mysticism beyond reality but firmly in the world. (I shall leave aside the question of Bergson's relationship to Eastern forms that may have been mediated through Plotinus).

Remarkably Bergson held that the portal to worldly mysticism lied through self-intuition of the continuous unfolding of life, by the immediate intuition of what is lived through. Once reality broke down, the world would reveal unexpected phenomena such as the indestructability of the past and non-ordinary experiences such as "telepathy, clairvoyance, mediumship, possession states and mystical experiences." 3 Of course it is difficult for even the most practical of us moderns to hold on to a simple distinction between reality and world even in everyday life as a result of creatively destructive forms of change, leading incessantly to the dissolution 
of what seemed to be the only realistic way of doing things and the questioning of who really has the qualifications or standing for determinate activities. Reality always already seems to be breaking down in the face of the possibilities in the world, and the world seems, then, to be recomposed as stable reality only to dissolve soon again into a world of new possibilities. Modern life itself thus accustoms us, in a manner, to the transcendence of the real for exploration of the world beyond it. Luc Boltanski has recently referred to this experience with the unseemly but helpful neologism of "wol\&real": "the reality of reality" and "the whatness of what is" never holds.4 Georg Simmel had already appropriated Bergson's vitalist metaphysics to capture this distinction as one between forms that life itself must take for activity to be coordinated and oriented and life that chafes at those forms that no longer serve its expression; in other words, the distinction between reality and world became one between mehr-als-leben (more than life) and mehr-leben (more life). ${ }^{5}$

Yet Bergson's metaphysics of worldly intuition is at a radical distance from an identification with incessant changes of modern economic life. Following the economist Joseph Schumpeter's description of modern economic change as creative destruction, I refer here to the dynamics the composition and re-composition of reality as regimes of practice, whether that change be driven by emergent elites attempting to escape limits on newfound powers or even subalterns sensing possibilities in once inchoate utopian hopes. Bergson's metaphysics gives expression not to such dynamics of modern social life but rather bespeaks of an experiential need go beyond reality and shatter the strictures of practical sense. Bergson gives philosophical expression to a radical desire for a worldly mysticism. Bergson would seem then to be not even a philosopher of politics, much less of war.

What remains astonishing to this day is the appeal that the Great War had as a mystical experience to leading intellectuals, most of all in Germany, where Bergson was often welcomed as a German thinker. The mystical experience that Bergson sought through the reception of art works and séances others found in the totalizing experience of war. Even in this anodyne lecture Bergson underlines that the imminence of death frees one from the selective memory required for continuing action so that one is plunged into the virtual whole of one's own life, freeing the self to recover memories long thought lost. At this moment of death then one enjoys la vision panoramique du passé; thus even before the War, Bergson already connected the achievement of mystical experience with the sense of death.

The point here is, then, different from the now jejune criticism of Bergson's vitalist doctrines for giving expression to the felt need for imperial expansion freed of the limits set in and through parliamentary discourse. Bergson is indeed often understood as an irrationalist and antiindividualistic philosopher who unwittingly prepared the groundwork for the dissolution of individuals into irredentist nationalist projects of limitless 
expansion, which propagandists troped as life, creativity and movement. This has certainly been a political form of what I have called mnemic vitalism to which Bergson's philosophy does open itself at times. ${ }^{6}$

But Bergson would go to great pains to distance himself from what he himself called the counterfeit mysticism of imperial expansion in his last work Two Sources of Religion and Morality and instead propose a decentralized vision of austere communities in which Europeans live simply until dying gracefully, with confidence of their spiritual selves outliving the disintegration of their material bodies. Even in his most jingoistic war-time propaganda, as I shall show, Bergson would not allow the conception of the élan vital to be pressed into the service of an untethered French nationalism.

Yet Lebensphilosophie, which had huge acknowledged and unacknowledged debts to Bergson, gave powerful expression to a profound dissatisfaction with nature of experience in modern life. Hans Joas and Wolfgang Knöbl have recently presented a masterful summary that the meaning the Great War had for many leading intellectuals in Germany and elsewhere:

Georg Simmel and Max Scheler interpreted the First World War as a chance to break with the tragic tendencies of modern culture, and believed that they could discern in the war the deeply moving existential experience of an ecstatic sense of security within a community - an experience that liberates us as individuals from all fixed schema, rendering us moldable again. [...] Even before the First World War, in the shape of British "Vorticism" around Ezra Pound and Wyndham Lewis, Italian futurism around Filippo Tommaso Marinetti, and German expressionism, there were artistic currents whose representatives tried to break free from a world that they saw as overly standardized or goal-oriented, and thus destructive of freedom. For this artistic avant garde, "violence" seemed a metaphor though which one could escape these constraints, and a war with no discernible enemy or soldiers, a war merely for its own sake and thus devoid of any real meaning, seemed a strange but viable way out of the malaise. [...] A generation of intellectuals deeply influenced by Nietzsche, Bergson and Sorel seemed ready and willing to break free from the world as it was, and the mythology of violence produced by the likes of Sorel seemed equally attractive to both Left and Right, though in the age of nationalist movements it is no surprise that these ideas often seemed easier to realize with the help of the nation than an abstract humanity. When it did in fact break out, the war could then be interpreted as the fulfillment of all hopes - however strange that may seem to us today. War was viewed by many, including German intellectuals, as the great chance to gain an identity, an opportunity to enter new dimensions of experience. Not only this, 
but armed violence could be interpreted as a form of action beyond utility maximization and strict adherence to norms. [...] War, Simmel tells us, entails entirely new dimensions of experience for most people. [...] Simmel is sure that "somehow this war means something different from other wars, that it has what I shall call a mysterious inner dimension."7

One of these dimensions of experience was wholeness, a sense of inclusive unity. I shall focus on it here though it should be underlined that the celebration of war in non-instrumental terms resonated with the deeply felt desire to be free of the modern mentality of calculation and Zweckrationalität and Bergson's critique of the intellect as an instrument for survival that had come to blunt man's higher intuitive capacities for spiritual truth. In what Thomas Mann called at the time of the War Kriegsideologie, intellectuals unabashedly celebrated people gaining a sense of being a unit raised together in such a way that no single member's destiny is different from any other's. German philosophers found resources to valorize such experience in Fichte's communitarianism and Bergson's anti-intellectualist philosophy of non-ordinary experience or mysticism, not in his official political statements. Indeed, Simmel who described Bergson as the greatest mind of contemporary philosophers was taken aback by his anti-German sentiments during the War, though he could not but underline his intellectual debts to a great philosopher and insist that the Germany of which Bergson had become suspicious had itself been changed by the experience of the War. ${ }^{8}$

Implicit in Bergson's idea of dureé is a sense of inclusive unity far more radical than the dominant image of it derived from the theory of real numbers and the real number line, and Bergson was from the outset a philosopher of mathematics, discussing a theory of numerical multiplicity and Zeno Paradoxes in his first book Time and Free Will. I want to compare first Bergson's idea of unity to common mathematical conceptions of the continuous and then suggest that his idea of oneness or unity can abstracted from dureé as experienced in the flow of a singular life. It was this abstract conception of oneness that found concrete expression in war mobilization, leading to its valorization as a form of Bergsonian mysticism.

The real numbers include positive and negative integers, fractions, square roots and transcendental numbers like $\square$; they all have a specific location on the real line which serves as a model of the real numbers. The real numbers are composed of rational and irrational numbers. Even though the latter are infinite and non-repeating, each is one number with a precise value and location on the number line. A property of the real numbers is that they have no gaps, which is why the real numbers appear to be a model of the continuous rather than the discrete in that they can be represented as a line-and this is astonishing - that having no breaks or gaps is whole or unified. In William Byers terms the real numbers give a powerful sense of inclusive unity. While Bergson suggested an even deeper sense of inclusive 
unity, it is best to clarify why the real number line seems to be an example of it. Byers writes,

The aspect of continuity that the real numbers capture is gaplessness, since the real number line has no holes. What does this mean? Suppose you divide all the real numbers into two sets $\mathrm{A}$ and $\mathrm{B}$, with the property that every element of A is smaller than any element of B. You could imagine cutting a horizontal line with a knife, with A consisting of all points on the line of the left of the cut, and $\mathrm{B}$ consisting of those numbers to the right of the cut. For the real numbers, there is always exactly one number that corresponds to the cut, call in $N$; The number $N$ is larger than every element of $\mathrm{A}$ (other than possibly itself) and smaller than every element of $\mathrm{B}$ (also possibly excluding itself). If there was a cut that did not correspond to some specific number, we may say that the real numbers have a gap, but it turns out that the real numbers can be characterized by the property of containing no gaps in precisely this sense. ${ }^{9}$

Byers goes on to explain that the rational (as opposed to the real) number line actually has many gaps, but even the real number line as a continuum of infinite discrete points gives a false representation of the continuous, wholeness and oneness for Bergson. Barry Allen puts it well: "A line is mathematically continuous without being interpenetrating. Every point is absolutely external to every other. But a mathematical continuum is not the only or obviously best model of continuity in nature. For one thing, it is not really continuous. One cannot find a hole in this continuum, that is true, yet the continuity is nothing but discontinuity endlessly repeated." 10 That the weakened form of discreteness implicit in the real number line may actually make it a better picture of nature in light of phenomena such as quantization and digital technology is a question that I shall leave aside. But, as Byers notes, it remains an open question whether reality is continuous and the discrete are approximations or whether reality is discrete and that the continuous is a different kind of approximation-what is called interpolation by which he means the process of filling in the gaps. ${ }^{11}$ Byers insists on the rightness of both views.

The point here is that for Bergson the sense of oneness created by the continuous cannot be mathematically represented but only intuited. Bergson's criticism cuts even deeper as what the real number line in which individual numbers perhaps only seem to follow each other seamlessly cannot represent is the interpenetration of all moments with each other. ${ }^{12}$ In this sense Bergsonian durée can only be properly appreciated as a radicalization of the sense of inclusive unity provided by the real number line. Intuition reveals for Bergson not only a deeper sense of unity but also a keener awareness of heterogeneity as not only is each unfolding moment interpenetrated with the whole but also is novel as a result of its 
condensation of an ever unique past. Bergson's durée expresses and resolves the ambiguity in the very idea of unity in that he fuses both the "universal," with the sense the "all-embracing" with the primitive root, "uni," a single slash or tally mark. Each new moment is singular but infused with the whole that is continuous and thus whole or unified. Bergsonian oneness is both universal and singular. ${ }^{13}$ This radical sense of qualitative multiplicity that Bergson tries to capture through intuitive insight captures a radically new sense of what I shall call dynamic inclusive unity.

What Byers says of the inclusive unity modeled by the real number line applies potentially with even greater force to what I have call dynamic inclusive unity:

The property of having no gaps is a defining property of the real number system and the reason why the system of real numbers so effectively models the continuous. This is another way in which the continuous refers back to the inclusive form of unity. When you say that you are one with somebody or some group, the essential thing is that, for the moment, nothing separates you from the group. The focus is on the larger unit of which you all form a part. Modern history is full of episodes of nationalism and ideology, where individuals lose themselves in a country or race or political party or merely in being a fan of some sports team. In these cases we can see how powerful the sense of inclusive unity can be. ${ }^{14}$

Joas and others have laid out how widespread support for the War was in Germany among intellectuals due to how war mobilization had created the process of unifying people inclusively in way that a new unified people would emerge. Indeed, this is why Simmel believed that Bergson's criticisms of the German people no longer had force. That is to say, war was militated for in religious terms for the way in which it broke down fragmented bourgeois reality to create a mystical experience of dynamic inclusive oneness and thereby realize for a people as a whole the profound spiritual truth of which Bergson's philosophy was understood to have given premonitory expression against the demands of instrumental intelligence and the classificatory logics of positivism.

But of course Bergson himself rightfully derived no such mystical defense of War from his philosophy as the German philosophers inspired by him had, and it is clear that Bergson's deliberately ambiguous conception of oneness puts the "uni" or the singular on the same ontological footing as the universal or all-embracing - a melody in which each unfolding note holds its own as it is interpenetrated with the whole is still an unsurpassed example of Bergson's radical sense of dynamic inclusive unity - and thus does not find reflection in total war mobilization in which the individual is simply effaced at the altar of national power. 
Yet Bergson's war writings, not simply their reception elsewhere, do deserve a critical reading. In closing this short piece, I shall suggest that the tragedy of War forced Bergson to modify his doctrines to shield them from being implicated in it. In light of the previous discussion it is particularly interesting that Bergson defended the French cause with arguments from Lebensphilosophie as had his counterparts in defense of the German cause. Enthusiastically putting his creative vitalist metaphysics in the service of war, Bergson supported Belgium's struggle against Prussia in 1914, writing of Prussia as a metaphysical problem in the grandest sense:

Many years hence, when the reaction of the past shall have left only the grand outline in view, this perhaps is how a philosopher will speak of it. He will say that the idea, peculiar to the nineteenth century, of employing science in the satisfaction of our material wants had given a wholly unforeseen extension to the mechanical arts and had equipped man in less than fifty years with more tools than he had made during the thousands of years he had lived on the earth. Each new machine being for man a new organ-an artificial organ which merely prolongs the natural organs-his body became suddenly and prodigiously increased in size, without his soul being able at the same time to dilate to the dimensions of his new body. From this disproportion there issued the problems, moral, social, international, which most of the nations endeavoured to solve by filling up the soulless void in the body politic by creating more liberty, more fraternity, more justice than the world had ever seen. Now, while mankind laboured at this task of spiritualization, inferior powers-I was going to say infernal powers-plotted an inverse experience for mankind. What would happen if the mechanical forces, which science had brought to a state of readiness for the service of man, should themselves take possession of man in order to make his nature material as their own? What kind of a world would it be if this mechanism should seize the human race entire, and if the peoples, instead of raising themselves to a richer and more harmonious diversity, as persons may do, were to fall into the uniformity of things? What kind of a society would that be which should mechanically obey a word of command mechanically transmitted; which should rule its science and its conscience in accordance therewith; and which should lose, along with the sense of justice, the power to discern between truth and falsehood? What would mankind be when brute force should hold the place of moral force? What new barbarism, this time final, would arise from these conditions to stifle feeling, ideas, and the whole civilization of which the old barbarism contained the germ? What would happen, in short, if the moral effort of humanity should turn in its tracks at the moment of attaining its goal, and if some diabolical contrivance should cause it to produce the 
mechanization of spirit instead of the spiritualization of matter? There was a people predestined to try the experiment. Prussia had been militarized by Prussia; a powerful nation was on the spot marching forward in its mechanical order. Administration and military mechanism were only waiting to make alliance with industrial mechanism. The combination once made, a formidable machine would come into existence. A touch upon the starting-gear and the other nations would be dragged in the wake of Germany, subjects to the same movement, prisoners of the same mechanism. ${ }^{15}$

Let me restate Bergson's argument as I understand it. Technology (telecommunications, railways, intermodal freight transportation) gives us a world beyond the human scale, connecting us over distances that we cannot easily imagine (the connected world is beyond imagining, contra Benedict Anderson); such an open and connected world depends on a share culture of liberty to ensure that the inevitable conflicts, as nations are brought together by what would later be called the technological annihilation of space and time, are adjudicated peacefully and justly. So Bergson foreshadows here his later work in the League of Nations. He recognizes that even those who have an interest in liberty and peace may, however, have lost their political will because one and the same technology that has created the post-human world has reduced many them, in their working lives, to appendages of machinery, if not machines or even matter. Drilled into obedience, they are thus easily manipulated by those intent on aggrandizing material power above all else, and have little will of their own to create an open cooperative society of liberty and justice (it was of course implied that such relations were not meant to be extended to the colonies). Beating back mechanism and matter, France and Belgium remain infused with the creative élan; Prussia is reduced to inertness. Descartes had speculated: "I remember that, when looking from a window and saying I see men who pass in the street, I really do not see them, but infer that what I see is men [...] and yet what do I see from the window but hats and coats which may cover automatic machines [whose motions might be determined by springs]."16 This most stunning expression of the mechanical philosophy - the idea that as one looks down at the street from the upper story of house what one sees may not be people at all but automata wearing hats and coats-culminates in war propaganda where the ambiguous passersby have become entire national populations. At the same time, Bergson understands the Belgian and French masses as carriers of the élan vital for a world now beyond the human individual and even the nation-state. The scope of the new society puts strains on all the actors involved, but it can be realized by a creative force cosmic in its reach. The Great War is thus reconfigured as a battle of life and matter over the future of the post-human world.

While Bergson's tract is indeed jingoistic, he does clarify his understanding of the élan vital in ways that would prove important for his 
later ethical and political interventions. Simply put, Bergson does not simply defend France for its vitality, for Germany too has a sense of vitality though without any respect for the rule of law. Bergson now insists that vital energy can only be sustained by ideals of freedom and justice higher than the life force itself. ${ }^{17}$ In one stroke, in the face of war, Bergson's metaphysics became more teleological and transcendent than it had been, for it had been a defining characteristic of durée that it was neither deterministic nor finalistic. By the end of his war tract, Bergson had revised those philosophical positions that had led to the criticism of Muhammed Iqbal who wrote in sympathetic criticism:

Again, in Bergson's view, the forward rush of the vital impulse in its creative freedom is unilluminated by the light of an immediate or remote purpose. It is not aiming at a result; it is wholly arbitrary, undirected, chaotic, and enforceable in its behaviors. [...] He regards conscious experience as the past moving along with and operating in the present. He ignores the unity of consciousness has a forward aspect also. Life is only a series of acts of attention, and an act of attention is inexplicable without reference to a purpose, conscious or unconscious. [...] Reality is not a blind vital impulse wholly unilluminated by idea. Its nature is through and through teleological. ${ }^{18}$

It is often said that Bergson put his metaphysics in the service of war, but this was not without his modifying the core of his philosophy. The War brought to a culmination the horrific implications of life philosophies, and led either to their future disguising as a Romantic pseudo-Darwinism or existentialism and, in Bergson's case, its modification towards explicitly humanistic ends.

1 Henri Bergson, "The Perception of Change" in Henri Bergson: Key Writings, ed. Keith Ansell Pearson and John Mullarkey and trans. Melissa McMahon (New York: Continuum Press, 2002): 248-266.

2 See discussion of the breakdown of corpuscular models in Milič Čapek, Bergson and Modern Physics: A Reinterpretation and Revaluation (Dordrecht, Holland: D. Reidel Publishing Company, 1971), 257-269.

${ }^{3}$ William Barnard, "Turning into Other Worlds: Henri Bergson and the Radio Reception Theory of Consciousness," in Bergson, Politics and Religion, ed. Alexandre Lefebvre and Melanie White (Durham: Duke University Press, 2012), 281. Barnard finds persuasive Bergson's defense of the authenticity of a woman's instantaneous vision of the death of her faraway soldier husband on the grounds that her vision was too detailed to be coincidence or a rational projection. As I shall argue, war provided its combatants more with genuinely mystical or, at least, far-from-theordinary experiences than the occasional alleged visionary glimpse. 
${ }^{4}$ Luc Boltanski, On Critique: A Sociology of Emancipation (London: Polity Press, 2011).

${ }^{5}$ Georg Simmel, The View of Life: Four Metaphysical Essays with Journal Aphorisms, trans. John A.Y. Andrews, Donald N. Levine and Daniel Silver (Chicago: University of Chicago Press, 2011).

${ }^{6}$ Donna Jones, The Racial Discourses of Life Philosophy: Négritude, Vitalism and Modernity (New York: Columbia University Press, 2010).

7 Hans Joas and Wolfgang Knöbl War in Social Thought: Hobbes to the Present, trans. Alex Skinner (Princeton: Princeton University Press, 2013), 134-136.

8 See Hans Joas Modernity and War, trans. Rodney Livingstone (London: Polity Press, 2003), 207208.

9 William Byers, The Blind Spot: Science and the Crisis of Uncertainty (Princeton: Princeton University Press, 2011), 145.

10 Barry Allen, "The Use of Useless Knowledge: Bergson against the Pragmatists," Canadian Journal of Philosophy (2013): 9-10; advance access on-line on 8 July, 2013.

${ }^{11}$ Byers, The Blind Spot, 147.

12 I have discussed this in terms of Markovian chains in Donna Jones "The Career of Living Things is Continuous: Reflections on Bergson, Iqbal and Scalia," Qui Parle, Vol. 20, No. 2 (Summer 2012).

${ }^{13}$ William Byers, How Mathematicians Think (Princeton: Princeton University Press, 2007), 206.

${ }^{14}$ Byers, The Blind Spot, 142-143.

${ }^{15}$ Henri Bergson, The Meaning of the War: Life \& Matter in Conflict (London: F.T. Unwin Publishers, 1915), 35-36.

${ }^{16}$ René Descartes, Meditations of First Philosophy (Kesinger Publications, 2004), 21.

${ }^{17}$ Bergson, The Meaning of War, 45-46. He was later perhaps insufficiently critical of France for not holding to its ideals of freedom and justice in its treatment of Germany at Versailles, perhaps because he was over-confident that France best embodied a vital spiritualism. Such idealism is hardly surprising however from a philosopher.

18 Muhammad Iqbal, The Reconstruction of Religious Thought in Islam (Lahore: Sangi-Meel Publications), 52-53. I am indebted here to Naveeda Khan, Muslim Becoming: Aspiration and Skepticism in Pakistan (Durham: Duke University Press, 2012) and Souleymane Bachir Diagne, Islam and the Open Society: Fidelity and Movement in the Philosophy of Muhammad Iqbal (Codesria Books, 2011). I comment on Diagne's profound studies of Bergson in the colonies in Donna Jones, "The Career of Living Things is Continuous" and in a book review in Journal of Anthropological Research, no. 69, vol. 1 (2013). 